\title{
Legal Nature and Legal Personality of the Self-regulatory Organizations (SRO)
}

Lubov Sitdikova

Maria Volkova

Svetlana Kuzahmetova

Olga Efimova

Olga Gridneva

Russian State Social University (RSSU), Moscow, Russian Federation building 1 Vilgelma Pika Street, 4, Moscow, 129226, Russian Federation

\section{Doi:10.5901/mjss.2015.v6n6s5p91}

\begin{abstract}
There is uncertainty whether self-regulatory organizations refer to the entities of public law or private entities. Russian legislator, on the one hand, has defined SRO as non-profit, based on the membership of subjects of professional and business activity (i.e. not created on the state initiative) organizations. On the other hand, they are organizations with authority to adopt regulations of professional business activities and control over their observance. Vesting of these powers on SRO has led to the fact that among scholars involved in research of questions of creation and activity of Russian self-regulatory organizations, the different points of view of their legal nature have been put forward: some of them have classified the SRO as subjects of public law, and the others consider them as private law entities. In scientific literature one can find opinions that SRO is a new legal form of legal entities that they belong to a special group of entities - "self-regulating". The authors consider different points of view of scientists, about the legal nature of self-regulatory organizations and make a conclusion about the presence of self-regulating organizations of the characteristics peculiar to both the private entity and the entity of public law, that allows us to talk about their mixed legal nature.
\end{abstract}

Keywords: self-regulation, legal nature, legal personality, non-profit organizations, entrepreneurship.

\section{Introduction}

\subsection{Introducing the Problem}

In accordance with the paragraph 1 of article 3 of the Law on self-regulating organizations self-regulatory organizations are non-profit organizations, established for purposes provided for by this Federal law and other Federal laws, based on the membership, uniting entities of entrepreneurial activity on the basis of the unity of the branch of production of goods (works, services), or market-produced goods (works, services), or uniting subjects of professional activity of a certain kind"

Article 2 of the same Law defines self-regulation as the self and initiative activity conducted by subjects of professional and business activity, and consists of the development and establishment of standards and regulations of such activity, and of the control over their observance.

The law on self-regulating organizations (hereinafter - SRO) in certain areas similarly enshrines the concept of the phenomena in question. For example, according to the article 31 of the Federal law "On advertising" self-regulating organization in the field of advertising are the association of advertisers, advertisement producers, advertisement distributor and other persons, created in the form of Association, Union or non-profit partnership for the purpose of representing and protecting of members' interests, development of the requirements of the observance of ethical norms in advertising and control over their fulfillment.

Article 2 of the Federal law "On insolvency (bankruptcy)" determines self-regulatory organisation of arbitration managers as a non-profit organization that is membership-based, created by citizens of the Russian Federation, information about which is hosted in the unified state register of self-regulatory organizations of arbitration managers, whose activities purposes are the regulation and support of activities of arbitration managers. 
According to the article 22 of the Federal law "On appraisal activity", the self-regulatory organization of appraisers is a non - profit organization established for the regulation and control of the evaluation activities, included in the unified state register of self-regulating organizations of appraisers, and united on the basis of membership of appraisers.

\subsection{Importance of the Problem}

Before the adoption of Federal law № 99, the right to carry out certain activities only upon compliance with the conditions about membership in self-regulatory organization (SRO) was fixed by some federal laws.

In the Civil Code of the Russian Federation, such provisions were absent, only a necessity of licensing in cases provided for by law was fixed in the Code (e.g., pursuant to par. 2 paragraph 3 of article 49 of the Code in its previous edition).

This norm was amended, now it indicates, in particular, that the right to exercise the activity for which it is necessary to be a member of SRO, arises from the moment of entry into the organization (clause 3 of article 49 of the Civil code).

In this regard there is a necessity of the analysis of the legal nature of self-regulatory organizations.

The educational and monographic works of the following authors were focused at the named topic: Kozlova N.V. (2003), Yastrebov O.A. (2009). Some aspects of the problem were analyzed in articles of the following authors: Volkov A.M. (2010); Denisov S.A. (2008); Zurina I.G. (2009); Sitdikova L.B. (2012); Tretyakova S.B. (2013).

The complex research of the different aspects of the problem was made in dissertation of Basova A.V. (2008).

Among the foreign sources we can distinguish the following: Black J. (1996); Hoofnagle Chris Jay (2005), Eric Nowak, Roland Rott, Till G. Mahr. (2004), Paton Paul (2008).

\subsection{Hypotheses and Their Correspondence to Research Design}

1.3.1. Special public powers of self-regulatory organizations, based on outsourcing, have been highlighted.

1.3.2. It is established that the self-regulatory organization possess features of a public law legal entity because of predominance of public purposes in its' activities.

1.3.3. It has been revealed, that the self-regulatory organizations are the private-law associations of entrepreneurs for consolidating professional interests. The main purpose of the SRO as a subject of private law is the regulation of relations between its members and consumers of their goods, works and services.

1.3.4. Despite the fact that SROs are the non-profit organizations, they are limitedly engaged in property relations.

\section{Method}

During the study the authors relied upon general and private methods of cognition: historical, legal, formal-legal, comparative legal, sociological and others. The main method is a system-structural which helped to reveal the legal nature of self-regulatory organizations in connection with other phenomena, as well as the existing problems in this area.

The combination of legal, historical and comparative legal methods allowed us to identify specific impact of the historical conditions at the development of self-regulation in Russia, in particular the combination of the of private and public legal nature.

Formal legal method made it possible to analyze legal rules governing self-regulatory organizations activity describing features of self-regulatory organizations (SRO), attributing them to subjects of private and public law.

On the basis of the sociological method, suggestions and recommendations are based with respect to the specific information obtained from official sources, materials, periodicals, Internet resources, standards, legal-reference systems and the media the grounded conclusions were made.

Systemic-structural method provided the authors with the opportunity to review the self-regulatory organizations as subjects of public and private law.

\section{Results and Discussion}

During the research we came to the conclusion, that the self-regulatory organizations do function both as participants of social relations and as public regulators performing normative and control functions, thereby realizing private and public interests.

The conclusion is made on vesting on self-regulating organizations of the private-law legal personality, the 
contents of which are subjective rights and obligations inherent to the Russian non-profit organizations as subjects of rights, and the special rights and duties associated with their role in process of self-regulation, which are implemented as a result of participation in a discretionary relations in certain limits provided by legislation.

Thus, we came to conclusion about SRO's mixed legal nature and its complex legal personality, containing mutually conditioned public-legal competence and civil legal personality.

Ambiguous legal nature of self-regulatory organizations has generated a lot of debate in the scientific community.

So, O.A. Yastrebov had considered possible definition of self-regulatory organizations as the public subjects of law, because they, in his opinion, are empowered with some public powers as a result of outsourcing, i.e. the mechanism of excretion of certain activities outside the scope of authority of the executive branch through contracts with outside performers on a competitive basis (O.A. Yastrebov, 2009, p.20).

A similar position is shared by A.M. Volkov. He considers that the transfer of such state powers as the development of standards and rules of professional or business activities, the supervision over compliance with the requirements of the specified standards and regulations by the members of self-regulatory organizations, the application of disciplinary measures against members of the self-regulatory organization, to self-regulatory organizations, are the signs of the legal entity of public law. (Volkov A.M., 2010, p.33)

I.G. Zhurina, considering them as a kind of non-profit organizations, notes that they belong to the entities of public law in the case of the predominance in their activities of public goals, on the achievement of which, in her opinion, the will of the uniting persons should be directed, and the availability of a special order of creation (I.G. Zhurina, 2009, p. 105).

As noted Sitdikova L.B., in national civil law until the legal fixation of the concept of "self-regulatory organization", the term "self-regulation" was not defined as a category of private law, and it has been used only to define the role of civil law as the regulator (Sitdikova L.B., 2012, p. 71-73).

The scientific position of scientists that recognize their dual nature seems fair. So, A. V. Basova believes that, on the one hand, self-regulatory organizations are the private-law associations of entrepreneurs consolidating professional interests. And on the other hand, they "perform public functions of regulation and control over business activities of its members" (A. V. Basov, 2008, p.96).

To determine the legal status of SROs in Russia, one should look at their socio-legal nature. In our view, it consists of the following.

1. Self-regulatory organizations create regulators of social relations (samples and measures of behavior) in the form of a set of standards and rules, sanctions, mandatory for participators in professional and business activity

2. SRO by creating samples and measures of behavior, stand as the element of the mechanism of social and legal regulation. For this self-regulatory organizations are vested with supervisory functions and funds to implement them. In particular, they give "permission" to conduct certain activities in form of tolerances, accreditations, produce membership of self-regulatory organization, they form and use compensation fund, check the activities of its members, apply disciplinary responsibility in case of violations, and so on.

Self-regulatory organizations participate in ordering, stabilization of social relations arising in connection with the observance of the SRO members of the applicable laws, including rules that determine the parameters for the conduct by them of entrepreneurial or professional activity.

Moreover, self-regulatory organizations organize relationships between their members and the consumers of their goods, works and services. According to S.B. Tretyakova these relationships are viewed as "...the relationship between members of the SRO and the self-regulatory organization itself" (S.B. Tretyakova, 2013, p.417).

3. Since the self-regulatory organizations are involved in the ordering of social relations, they aim to meet the interests of the subjects, which are involved in them. The analysis of the basic rights, duties and functions of SROs provided for in article 6 of the Law on self-regulating organizations, allows making a conclusion on the powers they possess.

In addition to the possibility of the regulation of the professional entrepreneurship activity of its members, which serves as the means of realizing public (public) interest, and consists of the regulation of social relations in a particular field, self-regulatory organizations also represent the interests of its members in their relations with public authorities of the Russian Federation, public authorities of subjects of the Russian Federation and bodies of local self-government, that violate the rights and legitimate interests of the self-regulatory organization, its member or threaten such violation, and so on.

Thus, self-regulatory organizations are, on the one hand, participants of the public relations, and, on the other, they regulate certain social relations in the sphere of professional and entrepreneurial activities, which are defined by law, 
performing normative (create regulators) and controlling functions. In addition, the Russian self-regulatory organizations implement both private and public interests.

Russian self-regulatory organizations are the nonprofit organizations that, in accordance with paragraph 1 of article 2 of the Federal law "On nonprofit organizations" (hereinafter - the Law on non-profit organizations), do not have profit as their primary purpose and do not share the profits among the participants, and in accordance with section 1 of article 14 of this law do not have the right to engage in entrepreneurial activities.

Thus, it is possible to conclude that the granting of the civil-law legal personality to the self-regulating organizations. The content of this legal personality are subjective rights and obligations inherent to the Russian non-profit organizations as subjects of rights, and the special rights and duties associated with their role in the process of selfregulation, implemented as a result of participation in a discretionary relations in certain limits, determined by the legislation. Such rights and obligations arise in connection with the provision of corporate management, forming of the property of the SRO, the placement of the compensation Fund, the selection of additional responsibility measures, the definition of how to interact with their members and so on (articles 12, $14-19$ of the Law on self-regulating organizations).

The obligatory membership in SRO cannot be regarded as a lack of freedom of will and passivity, because the potential member of the considered subject of law always has in the alternative, the rejection from membership and from carrying out professional and business activities. In other words, the creation or establishment of self-regulated organizations by the subjects of professional and business activities are the decisions of the mentioned subjects, and are not "initiated" by the state.

On the other hand, the legal status of the Russian self-regulatory organizations bears a public legal nature, due to the following:

1) the presence of public significant (public) purpose of the establishment and activity of the Russian selfregulatory organizations, consisting in the regulation of social relations in the field of professional and business activity enshrined in law (section 1 of article 3 of the Law on self-regulating organizations);

2) Russian self-regulatory organizations on the basis of rules of law are vested with public powers in establishing rules and standards and other means of regulation of the professional and business activity, and state powers for monitoring of the implementation, the provision of which is mandatory and is associated with positive responsibility of SRO for their implementation (articles 3, 4, 6 of the Law on self-regulating organizations). Their content is determined by the awareness of public interest and balanced with him in private (corporate), which together regulate the field of professional and business activity.

The vesting of the Russian self-regulatory organizations by state powers allows to speak about a public legal personality of the SRO. In addition to the powers such a legal personality includes the subject matter of reference (a certain type of professional and business entities, united in a self-regulatory organizations), the object of influence (social relations in the sphere of professional and entrepreneurial activities) and the state control over their execution. The material basis for the exercise of state powers constitute the corporate and property relations, in the implementation of which the rights and obligations that compose the content of legal personality, are exercised.

3) the activity of SROs is aimed at the fulfillment of the following public functions: a) creation of regulators of the professional and business activity (articles 3, 4, 5 of the Law on self-regulating organizations); b) methodological support professional and entrepreneurial activities (article 6 of the Law on self-regulating organizations); b) protection of rights and legitimate interests of members of self-regulatory organizations (article 6 of the Law on self-regulating organizations); d) protection of rights and legal interests of consumers of goods, works and services, performed by members of the self-regulatory organization (article 9, 10, 12, 13 Law on self-regulating organizations); d) provision of control over the activities of members of self-regulatory organization (article 9 and 10 of the Law on self-regulating organizations); e) interaction with state authorities, local authorities and third parties on questions of monitoring and improving the system of self-government (article 20, 21, 22, etc. of the Law on self-regulating organizations).

4) the law provides for the self-regulatory organizations a special procedure of identification, associated with the peculiarities of their creation: the presence of the additional registration in the register of SRO, obtaining a special permit, accreditation, etc. (article 3 of the Law on self-regulating organizations, article 48 of the Federal law "On securities market" and other).

5) for the exercise of powers, in accordance with article 19 of the Law on self-regulating organizations, the Russian SROs create specialized structures exercising monitoring powers in relation to members of selfregulatory organizations and examining cases on the application in relation to their disciplinary measures. 


\section{Conclusion}

Thus, SRO have characteristics both of private law and public law. This allows to make a conclusion about their mixed legal nature and, consequently, of complex legal personality, which contains public law competence and a civil law legal personality, which are mutually connected. The formation of a special legal array for the regulation the establishment and activities of self-regulatory organizations, and the available legal practice on this issue, shows the impossibility to regulate SRO on the basis of the general rules of law about collective subjects of law, and requires the allocation of self-regulatory organizations in particular as an independent subject of law.

\section{References}

Basova, A.V. (2008). Samoreguliruemije organizatsii kak subjecti predprenimatelskogo prava. Dissertatsija kandidata juridicheskih nauk [Self-regulatory organizations as the subjects of entrepreneur ship law: Candidate dissertation.] Moskva.

Black, J. (1996). Constitutionalising Self-regulation. Modern Law Review. January.

Denisov, S.A. (2008). Samoregulirovanije ili samoorganizatsija? [Self-regulation or self-organisation?] Grazdanskoye pravo sovremennoj Rossii. Moskva: Izdatel'stvo Statut.

Hoofnagle, Ch.J. (2005). Privacy Self Regulation: A Decade of Disappointment Retrieved from http://www.epic.org/reports/decade disappoint.html.

Nowak, E., Rott, R., Mahr T.G. (2004). Does self-regulation work in a civil law country? An empirical analysis of the declaration of conformity to the German Corporate Covernance Code. Retrieved from http://www.nccr-finrisk.uzh.ch/media/pdf/Nowak.pdf.

Paul, P. (2008). Self-regulation takes a beating abroad is Canada different? The Lawyers Weekly, Ottawa, Canada. Vol. 28, No. 24. Retrieved from http ://www. lawyers weekly. ca/index.php?section=article\& articleid=732

Sitdikova, L.B. (2012). Rol samoreguliruemih organizatsij v sisteme obespechenija kachestva konsultatsionnih uslug [The role of selfregulatory organizations in the consultancy services quality provision]. Juridicheskij mir, Vol. 2.

Tretyakova, S.B. (2013). Samoreguliruemaja organizatsija - osobij subject prava. [Self-regulatory organization - special subject of law]. Administrativnoje i munitsipalnoje pravo, Vol. 5.

Volkov, A.M. (2010). Juridicheskije litsa publichnogo prava v koncepcii razvitija zakonodatelstva o juridicheskih litsah [Legal entities of the public law in concept of the development of the legislation on legal entities]. Vestnik Rossijskogo Yniversiteta druzbi narodov: Seria Juridicheskije nauki, Vol. 1, 33-35.

Yastrebov, O.A. (2009). Nekommercheskije organizatsii kak subjekti publichnogo prava. [Non-profit organizations as the subjects of public law]. Moskva: Izdatel'stvo RUDN.

Zurina, I.G. (2009). Mozno li priznat samoreguliruemuju organizatsiju juridicheskim litsom publichnogo prava? [Is it possible to recognize self-regulatory organization as a legal entity of the public law?]. Advocat, Vol 6, 105-107. 